\title{
住民参加型コミュニティバス計画のための情報提示型システムに関する研究*
}

\section{A Study on a Support System for Community Bus Operation Planning with Citizen Participation*}

\author{
小山茂 $* * \cdot$ 谷口滋一 $* * * \cdot$ 蔪朝幸 $* * * * \cdot$ 大西貴佳 $* * * * *$ \\ By Shigeru KOYAMA** · Shigekazu YAGUCHI*** • Tomoyuki TODOROKI**** • Takayoshi OHNISHI ${ }^{* * * * *}$
}

\section{1. はじめに}

千葉県四街道市では、2001年にコミュニティバスを 導入し、公共交通の利便性向上に努めてきた。公共交通 の利便性向上を検討するにあたり、四街道市では、「市 民会議 ${ }^{1)} 」$ という形で住民参加型の計画づくりを進め ている。住民参加型の検討会議では、住民の意見に即し た具体的な計画をその場で提示することで、議論がより 深化することが期待できる2)-6)。

そのため本研究では、コミュニティバス運行計画を 支援するコンピュータシステムを構筑し、市民会議にお いて試用した。また、より広く住民の意向を収集するた め、We bを用いたアンケートシステムを構築し、運行 計画への適用可能性を検討した。

構築したシステムには、G I Sを用いた。杉尾ら ${ }^{7)}$ や日野ら ${ }^{8)}$ は、計画策定者がバス計画を行ううえで、 G I S を計画支援ツールとして用いることを念頭におい ている。一方、本研究は、コミュニティバスを対象とし、 住民が参加して計画を行うワークショップなどの場で住 民からの要望にもとづき、その場で計画路線を変更し、 議論を行うためのシステム構築を目指している。コミュ ニティバスは、一般の路線バスと比較して、地域住民の 足代わりとなる身近な存在であることから、住民の多様 なニーズにあった計画を行うべきと考えたためである。

\section{2. 四街道市におけるコミュニティバスの導入経過}

四街道市では公共交通不便地域があり、既存の民間 バス路線も廃止や縮小といった問題を抱えており、以前 より市内循環バスの導入を検討9)-12) してきた。 *キーワーズ : 公共交通計画、市民参加、G I S **正員、工修、札幌大学女子短期大学部 (北海道札幌市豊平区西岡 3 条 7 丁目 3 番 1 号、 TEL011-852-9342、FAX011-852-9342)

**正員、工博、専修大学商学部

***正員、工博、日本大学理工学部社会交通工学科 * *owk学生員、工学、日本大学大学院理工学研究科

(千葉県船橋市習志野台 7-2 4-1、 TEL047-469-5219、FAX047-469-5219)
そこで、四街道市は循環バスの路線、路線数、運行 時間帯などを検討するにあたり、市民の要望を把握する ため、循環バス利用意向アンケートを実施した（注：ア ンケート原案および解析については筆者らが担当した）。 アンケートは1999年11月に、15歳以上の3, 000名を各地 区の人口比率に忘じて無作為で抽出し、郵送配布・郵送 返却方式で実施した。回収されたアンケートは1,326部 で、回収率は44. $2 \%$ であった ${ }^{13)}$ 。

そのアンケート結果を踏まえ、2001年 3 月にコミュ ニティバス (循環バス) が導入され、愛称は四街道市の

「よ」とハッピーを合わせた「ヨッピイ」となった。そ の後、市民の要望により、2001年12月に運行ルートは若 干の変更が行われ、右回り・左回りともに駅一の到達時 間を早めるような形に変更された。四街道市循環バス

（以下、ヨッピィとする）の運行概要を表一1に、ヨッ ピィの運行路線図を図一 1 に示す。

\section{表ー 1 四街道市循環バスの概要}

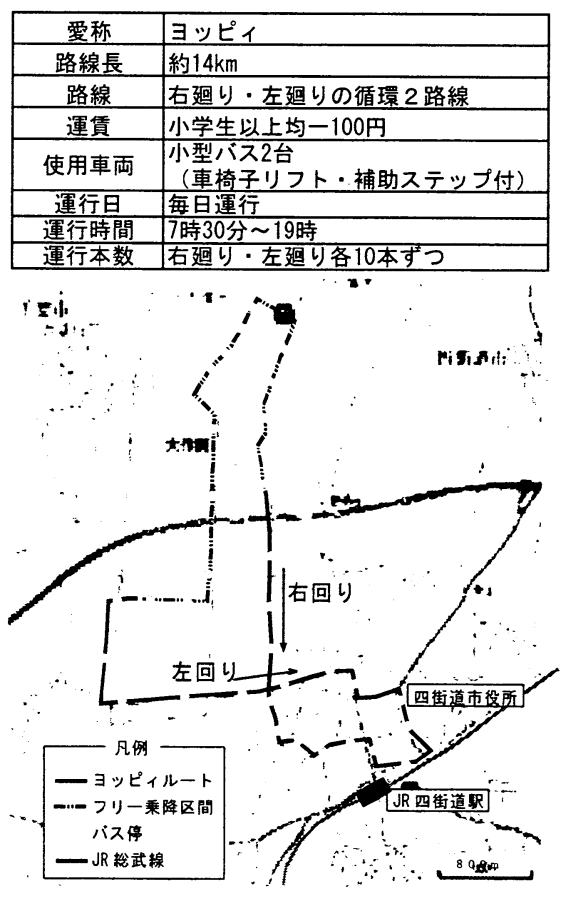

図ー1 ヨッピィ路線図 
四街道市はコミュニティバスを含めた公共交通の充 実を市民参加形式で行っていく方針であり、その中で四 街道市市民会議が2001年に発足した。市民会議には都市 基盤整備や環境整備など、分野ごとに分科会が設置され ており、その1つとしてヨッピイ分科会が設置された。 そこで、四街道市はコミュニティバスの導入効果および 他地域への導入を検討してきた。

住民参加型の検討会議では、住民の意見に即した具 体的な計画をその場で提示することで、議論がより深化 することが期待できる。そこで、筆者らは、コミュニテ イバス運行計画を支援するコンピュータシステムを構築 し、市民会議において試用した。

次章では、コミュニティバス運行計画支援システム の構築とその試用結果について説明する。

\section{3.コミュニティバス運行計画支援システム}

\section{（1）運行計画支援システムの概要}

筆者らは、市民会議のヨッピィ分科会において意見 交換しながら路線計画などが検討できる運行計画支援シ ステムの導入を提案した。

そこで、まず、GＩＳを用いてバス路線設定を簡便 に行える運行計画支援システムを構筑した。本研究で構 築した支援システムのフローを図一 2 に示す。また、初 期値設定およびコマンド選択を行うためのシステムフォ ームを図ー3に示す。

支援システムでは、画面地図上の道路網に路線を入 力すると、その路線長、所要時間が自動的に求められる。 そして、運行間隔、運行時間帯を入力すると、バス必要 台数が算出され、同時に運行経費が出力される。また、 設定した路線上の任意の場所にバス停を配置すると、バ ス停を中心とした勢力圈（勢力圈半径は任意に設定）が 描かれ、バス停勢力圈人口（総人口・年代別人口）が算 出される。最後に、四街道市が行った循環バス利用意向 アンケートの結果をもとにした利用意向割合から利用者 数を推計し、バス停勢力圈利用者内訳が出力されるシス テムである。このシステムを用いることにより、簡便に バス路線の代替案を検討することができる。

以下に、システム概要および使用したデータ概要を 示す。

\section{(1)地図データ}

本研究では、地図データとして、ゼンリンのZmap電 子地図「住居地図データベース」、およひ国土地理院の

「数值地図2500」を用いた。

(2)道路ネットワークデータ

国土地理院の「数值地図2500」をもとに、四街道市 内の道路でバスの通行が可能な幅員 $5 \mathrm{~m}$ 以上の道路のみ を抜粋した。

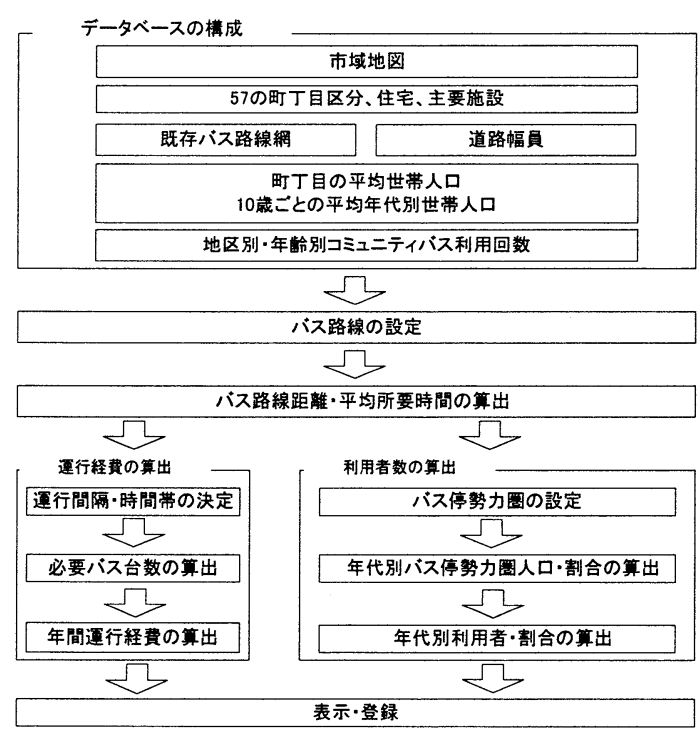

図ー2 支援システムのフロー

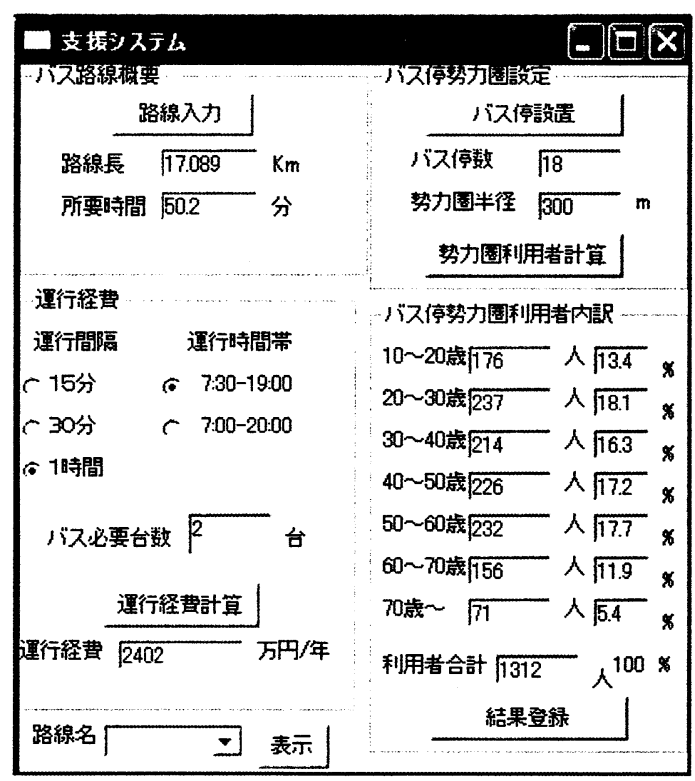

図ー3 支援システムフォーム

(3)主要施設データ

住民が日常的に利用する施設を、種類別に色別表示 した。その内訳は、学校 (黄色) ・病院 (水色) ・警察 署（青色）・郵便局（赤色）・行政関係（青緑色）・駅 (緑色) ・公共施設（黄緑色）・福祉施設（桃色）・商 業施設 (紫色)である。

(4)既存バス路線網データ

道路ネットワーク上に、四街道市内の既存バス路 線・既存バス停を入力した。また、各路線データを独立 したレイヤーへ入力することにより路線ごとの表示を可 能とした。 
(5)平均世帯人口・年代別平均世帯人口データ

人口データは、「平成12年度四街道市統計資料」14) をもとに構成し、各町丁目の平均世帯人口・年代別平均 世帯人口（本研究では10歳ごとにまとめた）を計算した。 この平均世帯人口・年代別平均世帯人口を属性データと

して、全住居のプロパティに属性データとして追加した。 さらに、コミュニティバスを導入するにあたっては、 高齢者（65歳以上）の利便性を確保するために高龄者率 の高い地域を考慮する必要がある。そこで、高齢者率を 0 5\%、5〜10\%、10〜15\%、15〜20\%、20\%以上の 5段階に分類し、色別表示 (高齢者率が高いほど濃色) を行った。

(6)アンケートデータ

地域によってコミュニティバスの利用意向が違って いるため、四街道市が実施したコミュニティバス導入に 関するアンケートをもとに、地域別・年齢別に将来循環 バスが導入された場合に利用すると回答した人の割合、 また週に何回利用するかという質問への回答を用い、コ ミュニティバス利用意向を推計した。

(7)バス平均所要時間の算出

平均所要時間はバス路線距離を表定速度で除したも ので計算できるが、本研究では、2000年8月21日（月） に行った四街道市内のバス主要 6 路線の旅行時間調查の 平均である $20.42 \mathrm{Km} / \mathrm{h}$ 用いた。

\section{8)運行経費の算出}

運行経費は既に四街道市で運行されているコミュニ ティバスの 1 台・1時間あたりの運行経費をべース額と した。まずバス路線長と所要時間をもとにバス必要台数 を算出し、さらに運行時間帯を決定することによって、 1時間あたりの運行経費から 1 日の経費を算出する。表 示結果は年間運行経費とした。

以上のデータを利用し、構筑した運行計画支援シス テムの表示画面を図ー4に示す。

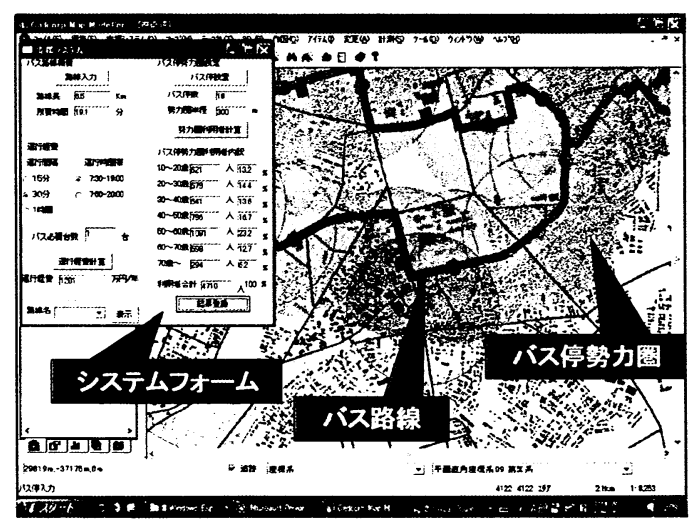

図ー4 運行計画支援システムの表示画面

\section{（2）運行計画支援システムの試用}

構筑した支援システムを、2002年 7 月 13 日（土）と 2003年 2 月13日（木）の2回、ヨッピイ分科会で試用し た。その概要を表一 2 に示す。

\section{表一2 支援システム適用時の分科会の概要}

\begin{tabular}{|c|c|c|}
\hline 実施年月日 & 実施した項目 & 参加人数 \\
\hline $\begin{array}{c}2002 \text { 年 } \\
\text { 7月13日 } \\
( \pm)\end{array}$ & $\begin{array}{l}\text { ·コミュニティバス計画方法の概要 } \\
\text { ·路線の提案 }\end{array}$ & $\begin{array}{l}\text { 市民: 15名 } \\
\text { 市職員:2名 } \\
\text { 日大:3名 }\end{array}$ \\
\hline $\begin{array}{c}\text { 2003年 } \\
\text { 2月13日 } \\
\text { (木) }\end{array}$ & $\begin{array}{l}\text {-コミュニティハス計画方法の概要 } \\
\text { - 分科会報告畫からの実践 } \\
\text { (運行経費·利用者数推計) } \\
\text {-参加者提示ルート萫の実践 }\end{array}$ & \begin{tabular}{|l} 
市民: 10 名 \\
市職員:2名 \\
日大:2名
\end{tabular} \\
\hline
\end{tabular}

四街道市はヨッピィを計画した当初、市内を $4 つ$ つ

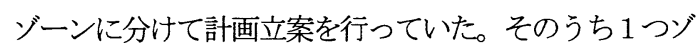
ーンにヨッピィは導入された。今回の検討では、残りの 3つのゾーンへの導入が主な検討対象となった。そこで、 第1回目の分科会においては、実現可能性の高い残りの

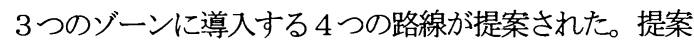
路線は、構築した支援システムを用いて提示した。

第 1 回目の分科会において提案した路線を図一 5 に 示す。
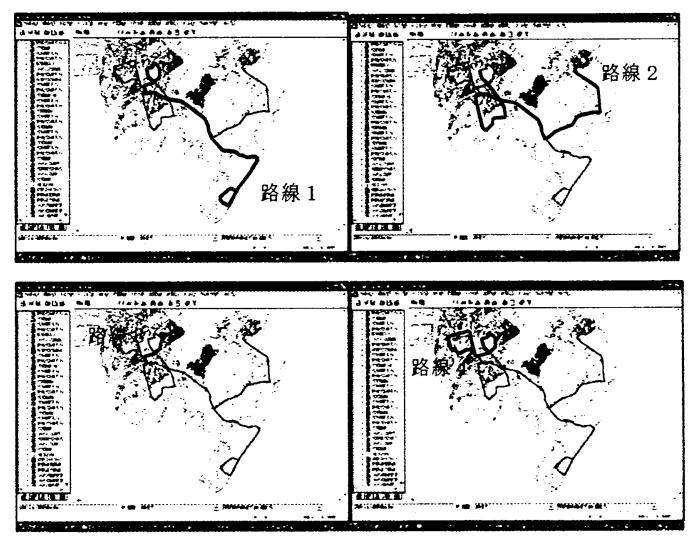

図一 5 提案路線（第1回目）

提案路線は駅や交通不便地域を $5 \sim 7 \mathrm{~km}$ 前後の路線 距離で循環できるルートとした。それぞれの提案路線は、

(1) 交通不便地域 3箇所

(2) 公共施設と不便地域

(3) 導入希望の多い地域と駅

(4) (3)現行路線の利用が多い地域

を結んだものである。

ここで、バス停の勢力圈半径は $300 \mathrm{~m}$ とて推計した。 勢力圈人口が最も多いのは(4)のルートであり、以下(1)、 (2、(3)の順であった。なお、第1回目では、勢力圏人口 
の計測のみを行った結果を提示し、運行経費や利用者数 の推計は支援システムに組み込んでいなかった。

路線案の提示後、それぞれの路線に関して参加者間 で意見交換を行った。その結果、勢力圈人口の多い(4)の 路線の評価が最も高い結果であった。一方で、運行経費 に関する不安についても意見が出された。この分科会の 成果は、報告書「交通不便地域の解消による四街道市の 活性化」 ${ }^{15)}$ にまとめられた。

第 1 回目の議論を受け、運行経費の算出と利用者を 簡便に推計できるよう支援システムを改良し、第2回目 の分科会でそれらの結果を含めて再度提示した。第 2 回 目の分科会において提案した路線を図一6に示す。

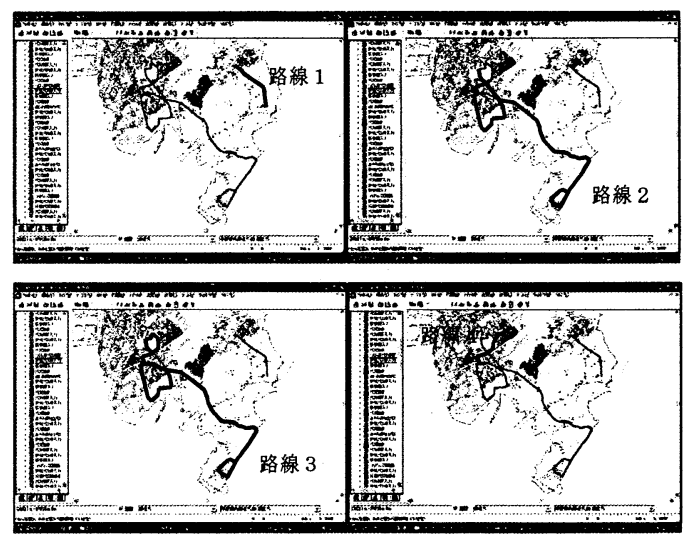

図-6 提案路線（第2回目）

第 2 回目の提案路線は、第 1 回目で参加者からの要 望があった路線を考慮して提案した。それぞれの提案路 線は、

(1) 既存路線バス終着部と交通不便地域 1 箇所

(2) 交通不便地域 2 箇所

(3) 交通不便地域 3 箇所

(4) 導入希望の多い地域々駅 (1回目提示路線(3) を結んだものである。これらの4路線に対して、それぞ れの運行経費と利用者数の推定結果を提示した。そして 提示後に参加者から意見を聞き、その意見を集約しなが ら実際に支援システムを用いて路線を設定し、利用者数 推計や運行経費の推計結果をその場で示しながら会議を 行った。

ここでの議論では、(4)の路線の評価が最も高く、前 回と同様に人口の多い地域を結ぶ路線であるためと思わ れる。

また提示後のアンケート調査において、このような 会議の場で必要と考える情報や支援について、それぞれ の項目を5段階で評価してもらった。その集計結果を表 -3に示す。このように沿線施設や沿線人口を考慮し、 専門家 (第三者) の意見を聞きながら、自分たちもコン
ピュータを使用した支援システムで理解を深めることに より、積極的に計画に参加することを望んでいることが 伺える結果であった。

\section{表ー3 導入計画における項目別重要度}

\begin{tabular}{|c|c|c|}
\hline & 計画を行ううえで必要な資料項目 & 得点 \\
\hline \multirow{6}{*}{$\begin{array}{l}\text { 計画 } \\
\text { 要素 }\end{array}$} & 公共施設や買物施設の位置 & 4.5 \\
\hline & 沿線人口 & 4.3 \\
\hline & 沿線の高龄者率 & 4.4 \\
\hline & 予測利用者数 & 4.2 \\
\hline & 他地域での運行事例 & 4.1 \\
\hline & 運行するのにかかる費用 & 3.9 \\
\hline \multirow{2}{*}{$\begin{array}{c}\text { 策定支援 } \\
\text { 要素 }\end{array}$} & コンピュータを使った支援システム & 4.6 \\
\hline & \begin{tabular}{|l|} 
専門家 (第三者) の協力 \\
\end{tabular} & 4.3 \\
\hline
\end{tabular}

住民参加のためのバス運行計画策定支援システムの 導入は、ある程度の成果が期待できる。しかし、分科会 による住民参加型の計画策定では、少数の限られた住民 の参加しかみられないため、多くの市民の意見を訊くこ とも重要である。

\section{We bによる市民意向アンケートシステム}

計画中のコミュニティバス路線に、より多くの住民 に関心を持ってもらい、運行計画策定において、市民の 意見を取り入れることは重要である。そこで、計画策定 に、より多くの市民を巻き込む方法として、コミュニテ イバスを対象としたWe bアンケートを行うことを提案 した。また、そのアンケートで得られた市民の意向を踏 まえた運行計画の試案を検討した。

\section{(1) We bアンケートシステムの概要}

We bアンケートシステムの概要を図ー 7 に示す。 We bアンケートシステムは、回答者にインターネット を用いてアンケートページにアクセスしてもらうことか ら始まり、アクセスパスワードの入力、導入是非や日常 外出、バスサービス水準に関するコミュニティバス利用 意向アンケートと進む。その後、地図上で回答者に自宅 地点をクリックしてもらうことにより、個人に即したバ 不路線情報を提示し、利用意向を尋ねる。そして最後に 個人属性に関する質問をするものとした。

We b アンケート調查ページの画面を図ー 8 に示す。 また、アンケート回答者の自宅選択画面を図一9に示す。 本研究で作成したシステムにG I Sを用いたのは、 自宅から最寄りバス停までの距離、バス停から目的地ま での乗車時間、目的地までの運賃、1 時間あたりの運行 本数など個人に即した情報を既存路線、提案路線別に表 示するためである。構筑したシステムは、回答者が個人 に即した詳しい情報をもとに、より実際に近い利用意向 
を回答できるものである。

回答者に提示した既存路線、提案路線別の路線選択 情報提供画面を図一10に示す。
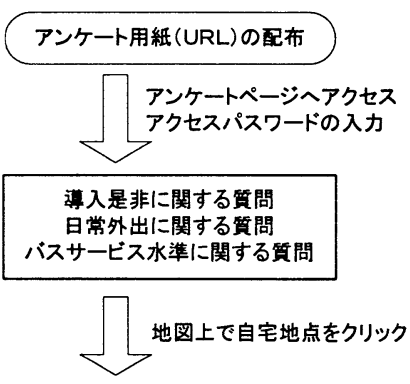

個人に即したバス路線情報の提示

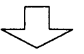

提示後の利用意向に関する筫問 個人風性に関する質問

図ー7 We bアンケートシステムの概要

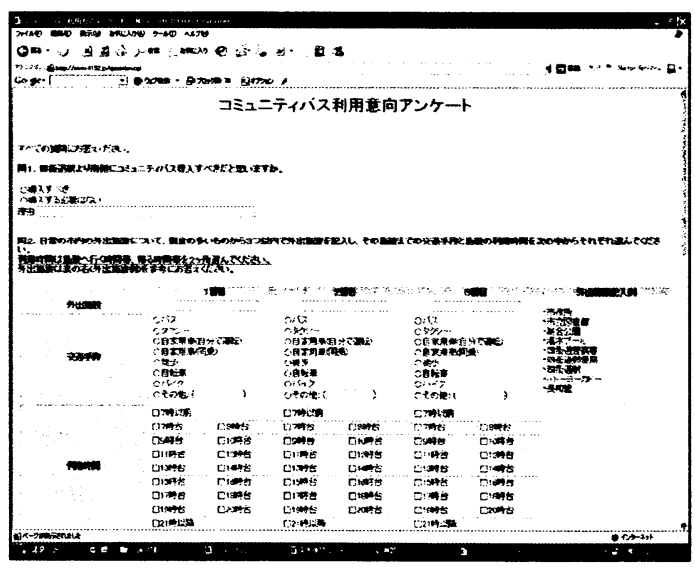

図ー8 We bアンケート調查ページ

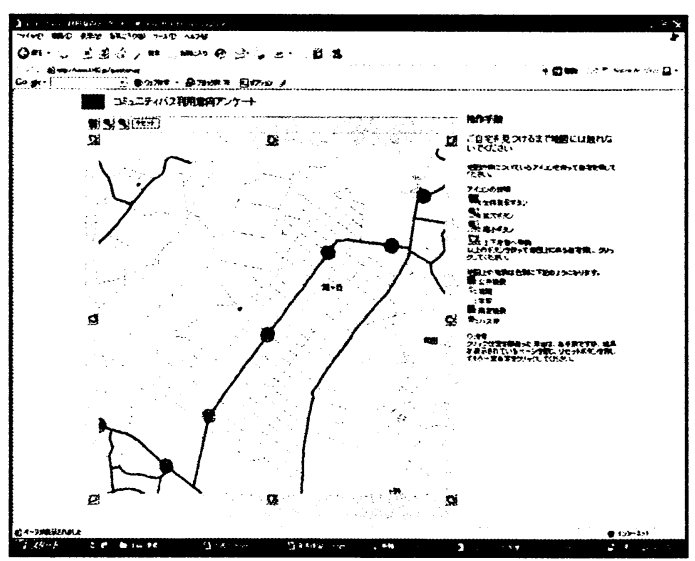

図ー9 アンケート回答者の自宅選択画面

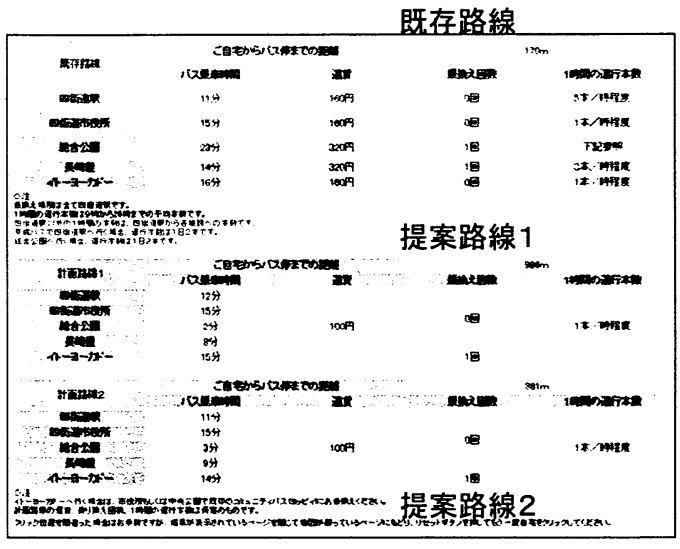

図-10 路線選択情報提供画面

ここで、図中の既存路線とは、既存の路線バスを利 用して目的地まで行ったときの各指標の推計結果であり、 提案路線とは、2003年に分科会等で検討した結果を踏ま えて、四街道市が検討している導入可能性の高い2 路線 を利用して目的地まで行ったときの推計結果である。提 案路線は、四街道市北部にはコミュニティバス路線があ るため、コミュニティバス導入の可能性が高い四街道市 南部 (JR総武本線以南地域) とした。

また、コミュニティバスのサービス水準の要望を調 査し、結果を分析して運行計画を決定するためにアンケ 一ト項目は以下の項目とした。

(1) 導入の是非、日常の外出施設とその交通手段

(2) 運行頻度・運賃・経由地などのサービス水淮

(3) 乗継ぎ・乗換え運貨などの割引運賃

(4) 共通券、低床車両導入などの付加サービス

(5)情報提示した後の利用意向とその理由

以上をもとに、利用者および近隣住民の要望を取り 入れたバス路線の変更・修正を行い、運行時間・運行間 隔、割引運賃などのサービス水隻設定の検討を試行する。

\section{（2）アンケート調査概要}

対象地域は、提案路線沿線の四街道市南部（JR総武 本線以南地域) とした。まず、対象地域の世帯数から地 区ごとの配布枚数を決定し、ホームページのUR Lを記 載したアンケート用紙 3,000 枚をポスティングで配布し た。しかし、予想していたよりも回答が集まらなかった ため、追加調査として、バス利用者に同様の用紙を 100 枚配布した。なお、調査期間は、2004年12月17日から 26 日および追加調査の 2005 年 1 月 7 日から16日までの 20 日 間とした。

調查結果は、アクセス数 48 件、有効回答数 34 件であ った。この回答率は、予想よりも悪い結果であった。 


\section{（3）アンケート結果と運行計画案の検討}

(1)コミュニティバス導入の是非とその理由を表一 4 に示す。この結果を見ると、90\%以上の回答者が必要と 答えており、多くがコミュニティバスの導入を望んでい た。また、導入理由に関しては、現状の公共交通に対す る不満、便利になるなどの改善を望むものが多数を占め ていた。

\section{表ー4 コミュニティバス導入の是非とその理由}

\begin{tabular}{|c|c|c|}
\hline & 項目 & 回答数 \\
\hline \multirow{11}{*}{$\begin{array}{l}\text { 嘎入 } \\
\text { 青定 }\end{array}$} & 現状の公共交通が不満 & 10 \\
\hline & 便利だから(雨天の場合を含む) & 6 \\
\hline & 駅周辺の渋滞対策として & 3 \\
\hline & 需要がある(ありそう)だから & 2 \\
\hline & 南側は起伏がおおく大変だから & 2 \\
\hline & 北側たシけでは不公平 & 2 \\
\hline & 自家用車以外の交通手段がない & 2 \\
\hline & 北側の施設への直通便がなく不便 & 1 \\
\hline & $\begin{array}{l}\text { 高齢になり自動車から公共交通に } \\
\text { 転換する(将来を含む) }\end{array}$ & 1 \\
\hline & $\begin{array}{l}\text { 施設は建設されたが公共交通では } \\
\text { アクセスできない }\end{array}$ & \\
\hline & 環境対策のため & 1 \\
\hline & 他の交通手段を利用するから & 2 \\
\hline & 市の中心部へ行く機会がないから & 1 \\
\hline
\end{tabular}

アンケート回答者の日常の外出施設を図ー11に示す。 日常の外出先は四街道駅が最も多く、またそこまでの交 通手段としてはバスと自転車が多い。つで、イトーヨ 一カドー、長崎屋のショッピング施設が続き、そこまで の交通手段としては自動車が主であった。その他の目的 地に対しても自動車の利用が多く、四街道駅以外の目的 地への交通手段としては、よく自動車が利用されていた。 この結果を踏まえ、提案路線を市役所から図書館ま で延長することが考えられる。

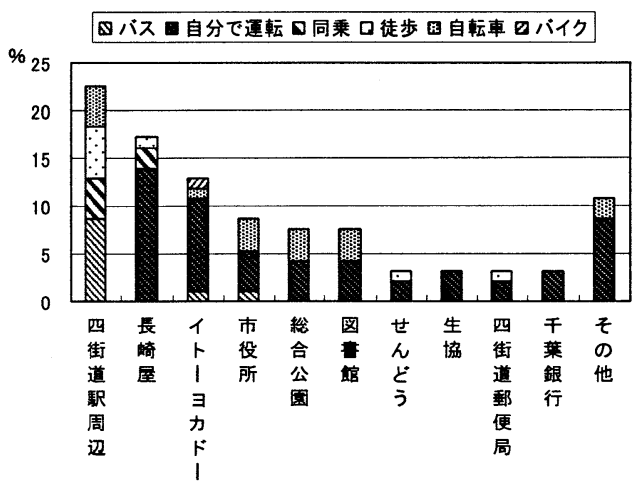

図ー11 アンケート回答者の日常の外出施設
(2)コミュニティバスの希望運行本数を図ー12に示す。 コミュニティバスの希望運行本数は、1時間あたり 2 本 から 4 本という希望が多かった。このことから、運行間 隔は15〜30分に 1本となり、需要増を期待すれば15分間 隔が望ましいと考えられる。ただし、運行可能車両など を勘案する必要がある。

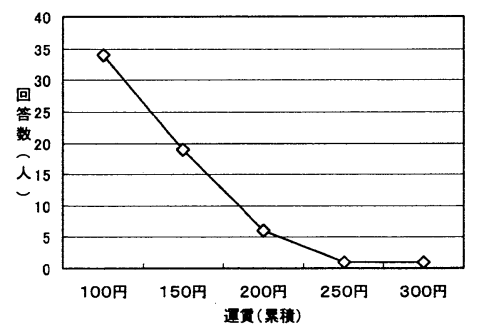

\section{図一12 コミュニティバスの希望運行本数}

(3)コミュニティバスの希望運賃を図ー13に示す。コ ミュニティバスの希望運賃は、150円以下という希望が 多かった。ただし、需要を見込むには100円と設定する ことが望ましい結果であったが、さらに採算性も併せて 検討する必要がある。

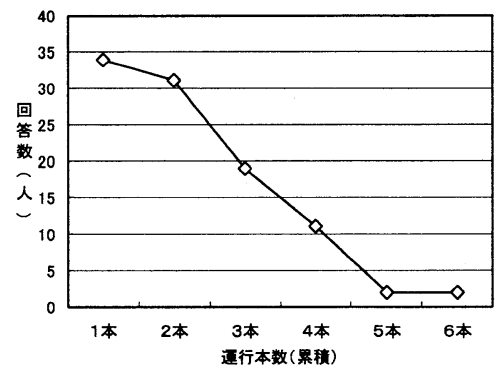

図一13 コミュニティバスの希望運貨

(4)その他のアンケート回答結果は、以下のようなも のであった。

経由希望施設としては、現在ヨッピィが運行してい る四街道駅・市役所以外に、図書館やその他の公共施設 という回答が多かった。

線路より北側を走るヨッピィとの乗継ぎ運賃につい ての項目では、80\%以上の回答者が乗継ぎ運賃があれば 利用すると答え、鉄道との乗換え運賃でも同様の結果で あった。このため、乗継ぎ、乗換え運賃の導入により利 用者の増加が見込めると考えられる。

また、付加サービスでは、「フリー乗降区間の設

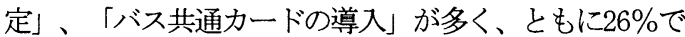
あった。

コミュニティバスが運行されたと仮定した場合の利 用意向では、提案路線 1が32\%、提案路線 2 が $24 \%$ 、ど 
ちらも利用しないが $44 \%$ でとなり、利用しても良い条件 では、「バス停が近くなれば」、「運行本数が増えれ ば」といら回答が多かった。

以上のアンケート回答結果から、コミュニティバス の計画案は、市民の意向を踏まえると運賃を100円、運 行頻度を 1 時間当たり 4 本とし、経由地に図書館を加え、 さらに、フリー乗降区間・バス共通カードを導入し、低 床車両で運行することが最良策と考えられる。ただし、 前述のとおりダイヤなどの運行可能性や事業採算性につ いてのさらなる検討が必要である。

\section{（4）We bアンケート導入の可能性に関する考察}

本W e b 調査を導入することで、市民意見の収集、 市民ニーズを考察した運行計画ができることが確認でき た。しかし、本W e b 調査で得られた回答数は少なく、 実際のバス路線を計画する場合には、より多くの市民の 意見を取り入れたほうがよい。そこで回答数が少ない原 因を、1999年に実施された四街道市循環バス利用意向ア ンケート (市)および2001年に実施された四街道市循環 バス利用者の交通行動調査 (利用者) と比較することに より、考察する。

回答者の年齢構成のアンケート調查別比較を図 -14 に示す。四街道市循環バス利用者の交通行動調查（利用 者）から、利用者の約 $30 \%$ 70 歳以上であった。本W e $\mathrm{b}$ 調査の回答者では約 $10 \%$ が70歳以上であり、実際のコ ミュニティバス利用者からの回答が得られていない結果 であった。

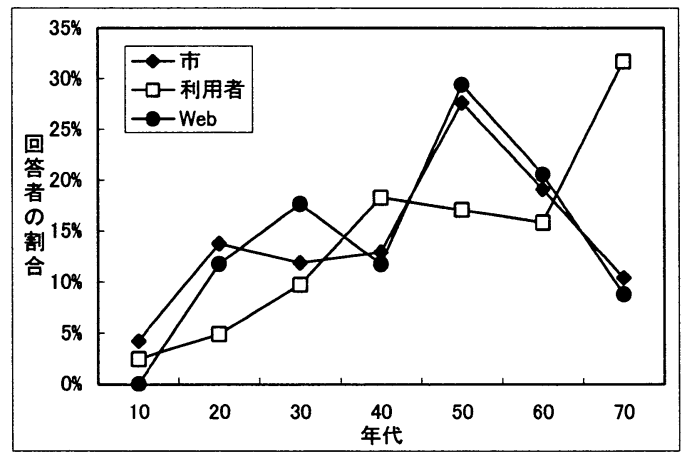

図-14 回答者年代のアンケート調査別比較

一方、四街道市循環バス利用意向アンケート（市） と本W e b 調査を比較すると年齢構成が一致しており、 用紙配布によるアンケートでも高齢者からの回答が得ら れていないことがわかる。したがって、アンケートの依 頼配布方法に問題があると推察できる。また、高龄者に 依頼できたとしても、コンピュータに不慣れであること から、回答が得られないことも考えられる。
そこで、高齢者の回答を増加させるための対策とし ては、比較的高齢者が参加している町内会や老人会など を通じて、アンケート依頼を行うことが考えられる。ま た、コンピュータに不慣れな高齢者のために、調査員が 出向いて、調査員がコンピュータ操作を行いながら、ア ンケート回答をしてもらうなどのインタビュー方式が考 えられる。第 3 章で実施した分科会でのように、W e b アンケートシステムを参加者全員で見ながら、意見交換 し、意見を集約することも有効と考えている。

\section{5. おわりに}

本研究では、コミュニティバス運行計画を支援する コンピュータシステムを構筑し、「市民会議」において 試用した。また、より広く住民の意向を収集するため、 We bを用いたアンケートシステムを構築し、適用可能 性を検討した。

その結果、住民参加のためのバス運行計画策定支援 システムの導入は、ある程度の成果が期待できることが わかった。しか、分科会による住民参加型の計画策定 では、少数の限られた住民の参加しかみられないため、 多くの市民の意見を訊くことも必要であることがわかっ た。

そこで、計画策定により多くの市民を巻き込む方法 として、コミュニティバスを対象としたW e bアンケー 卜を行うことを提案し、そのアンケートで得られた市民 の意向を踏まえた運行計画の試案を検討した。その結果、 本調査システムを導入することで、市民意見の収集、市 民ニーズにあった運行計画ができることが確認できた。

今後は、提案したシステムを多くの人に利用しても らうための対策として、町内会や老人会などを通じて、 アンケート依頼を行うことや、コンピュータに不慣れな 高齢者のために、調査員がコンピュータ操作を行いなが ら、アンケート回答をしてもらうこと、などの方法を検 証する必要がある。

最後に、本研究を行うにあたりご協力を頂いた千葉 県各市町村担当者の皆様、四街道市役所と市民の皆様、 ご指導を頂いた日本大学名誉教授榛澤芳雄博士、日本大 学理工学部教授福田敦博士、また共に研究を行った日本 大学理工学部・大学院卒業生の方々に心から感謝いたし ます。

\section{参考文献}

1）四街道市市民参加研究会 : 四街道市における市民参 加導入指針, 2001. 10.

2）梶浦恒男・金印曾 : インプルーブメント型まちづく りへの住民参加方式についての研究一庄内南・北地 
区における住民参加方式の考察と評価一, 第28回都 市計画学会学術研究論文集, pp. 805- 810, 1993.

3）谷下雅義 : 社会資本整備の計画策定手続における市 民参加，土木学会論文集，No. 681，IV-52，pp. 37-4 9, 2001.

4）三谷麻衣 - 久保田尚・坂本邦宏・御座元俊二 - 高橋 洋二 : 参加型地区交通改善のための合意形成手法に 関する研究一鎌倉・今小路通りにおける歩行者尊重 道路を対象として一, 第35回都市計画学会学術研究 論文集, pp. 487-492, 2000.

5）篠崎道彦: まちづくりと計画支援システム, 都市計 画, No. 211, p. 45-p. 48, 1998.

6）阿部浩之・湯沢昭 : ワークショップにおける合意形 成プロセスの評価, 第36回都市計画学会学術研究論 文集, pp. 55-60, 2001.

7）杉尾恵太・磯部友彦・竹内伝史：G I Sを用いたバ ス路線網計画支援システムの構築一潜在需要の把握 による路線評価について一, 土木計画学研究論文集 IV, No. 18, pp. 617-626, 2001.

8）日野 智・原口征人・佐藤馨一：地理情報システム による利用者平均所要時間の算定と公共交通路線の 評価に関する研究一札幌北部地域を対象として一, 第34回都市計画学会学術研究論文集, pp. 973-978,
1999.

9）コミュニティバスの動向に関する一考察, 小山茂・ 榛澤芳雄・金山拓郎, 土木計画学研究・講演集No. 2 4, CD No. 44, 2001.

10）四街道市におけるコミュニティバスの運行実態 に関する研究，金山拓郎・榛澤芳雄・小山茂，土木 計画学研究・講演集NNo. 24, CD No. 45, 2001.

1 1）四街道における市民バス導入の検討手法に関す る研究, 山中勇紀・榛澤芳雄・小山茂, 第21回交通 工学発表会論文集, pp. 77-80, 2001.

12）地区効用と利用変動を考慮したコミュニティバ スの導入計画に関する研究，谷口滋一・榛澤芳雄・ 小山茂, 第21回交通工学発表会論文集, pp. 81-84, 2001.

13）四街道市市内循環バス導入検討委員会 : 市内循 環バス導入検討報告, 2000 .

14）四街道市企画財政部 : 平成12年度四街道市統計 資料, 2000年.

15）交通不便地域の解消による四街道市の活性化： ヨッピイ分科会, 四街道市民プラン21, 2002.

\section{住民参加型コミュニティバス計画のための情報提示型システムに関する研究*}

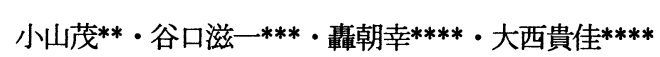

本論文では、G I Sを用いてコミュニティバス運行計画を支援するコンピュータシステムを構筑し、千葉県四街道市の「市民 会議」において試用し、その効果を明らかにした。さらに幅広く住民の意見を取り入れるための情報提示型We bアンケートシ ステムとその結果を踏まえたバス路線再編計画手法を提案し、導入可能性を検討した。その結果、システムを用いて住民の意見 を取り入れたバス路線計画が実施できることが確認できた。

\section{A Study on a Support System for Community Bus Operation Planning with Citizen Participation*} By Shigeru KOYAMA**-Shigekazu YAGUCHI***-Tomoyuki TODOROKI****-Takayoshi OHNISHI****

In this Paper, at first, a support system for community bus operating planning with citizen participation by geographic information system (GIS) was constructed. And the system was applied to planning of the "Yoppy" study meeting with citizens in Yotsukaido-city. As the result, it was revealed that the system was sufficient for effective community bus operation with citizen participant. And next, an web questionnaire system for surrounding citizen voices was proposed. The system was helpful for sounding out the citizen voice. 